Original paper UDC 001.8:001.53(045)

$165: 28(045)$

doi: $10.21464 / \mathrm{sp} 31205$

Received January $5^{\text {th }}, 2016$

\author{
Nader El-Bizri \\ American University of Beirut, Faculty of Arts and Sciences, Civilization Studies Program, \\ PO Box 11-0236, Riad El Solh, LB-1107 2020 Beirut \\ nb44@aub.edu.lb
}

\title{
Falsafa: A Labyrinth of Theory and Method
}

\section{Abstract}

This paper examines the theoretical underpinnings of methodologies that are used in studying falsafa (or what is commonly known as 'Arabic cum Islamic Philosophy'). The aim is to think about the prospects of renewing selected leitmotifs from the constellation of hybrid philosophical traditions in falsafa, while transcending the conventions of mainstream academia and scholarship, with their bent on documentation, archiving, and the composition of comparative studies and commentaries. The thematic orientation of this inquiry does not follow the directives of mediaevalists in historiography, philology, lexicography, codicology, and palaeography, along with their associated biographical/bibliographical instruments. We do not, therefore, focus on specific pre-modern authors or texts, or ponder over the techniques of establishing critical editions, annotated translations, or analytic, historical, and comparative commentaries. We also do not seek to situate a given philosophical legacy within its channels of textual transmission, or to explore its course of development within a particular intellectual lineage. Our inquiry is rather orientated within this specific conceptual exercise by phenomenological hermeneutics and critical analytics of the theoretical underpinnings of methodologies that aim at examining essential questions in ontology and epistemology in connection with falsafa. This points to transcending mere comparativism through a radical form of questioning that refracts intellectual traditions with one another based on substantiated historical channels of transmission by inheriting past philosophical legacies within contemporary pathways in thinking. Such an undertaking addresses multifactorial hypotheses that emerge from the humanistic disciplines in terms of theoretical disputations and interrogations over the essence of modernity and of probing the hitherto locked possibilities of potentially rooting contemporary thought in inherited intellectual legacies, and also in benefiting from modern thinking in exploring the history of ideas in Islam as a living tradition.
\end{abstract}

\section{Keywords}

comparativism, falsafa, methodology, modernity, religion, science, theory, tradition

"Das Älteste der Alten kommt in unserem Denken hinter uns her und doch auf uns zu."

[The oldest of the old follows behind us in our thinking and yet comes to meet us.]

Martin Heidegger ${ }^{1}$

Martin Heidegger, Aus der Erfahrung des Denkens, Pfullingen: Günther Neske Verlag, 1954, p. 19 


\section{Preamble}

This inquiry focuses on entwined theoretical and methodological interrogations that pertain to reflecting on contemporary academic approaches to studying falsafa, which in mainstream scholarship is designated under the appellations 'Arabic or Islamic Philosophy', and is historically a coined Arabic expression that referred to philosophy per se. For the sake of clarifying our perspective on the question at hand, we define the use of the term 'falsafa' in this context as: a constellation of pre-modern hybrid philosophical traditions of ancient Greek provenance, that were composed primarily in their historical greater part through the classical Arabic language, with principal textual prolongations written mainly in the Persian and Ottoman/Turkish languages, and rooted in the past within intellectual contexts underpinned by Islam and Abrahamic monotheism, with some of its selected discourses being still partially reproduced within certain curricula of the seminarian system (hawza) in the Twelver Shi' $i$ Muslim milieu. ${ }^{2}$

The thematic orientation of this present inquiry does not follow the conventional academic pathways in studying falsafa that are principally conducted from the viewpoint of investigating the history of ideas in Islam or pre-modern Arabic thought via the directives in scholarship of mediaevalists, which are analytically grounded on historiography, philology, lexicography, codicology, and palaeography, with associated biographical/bibliographical instruments. Our aim is not, therefore, to study specific pre-modern authors or texts, or ponder over the conventions and technicalities of establishing critical editions, annotated translations, or composing paraphrased analytic, historical, or comparative commentaries. Nor is our endeavour set to situate a given philosophical legacy within its own context of textual transmission, or explore the course of development of thought within a particular lineage or school. Our penchant in thinking is rather orientated in this specific exercise herein by phenomenological hermeneutics and critical analytics of the theoretical underpinnings of methodologies that aim at examining essential questions in ontology and epistemology, while grasping falsafa as being: a labyrinthine, hybrid, inherited intellectual legacy within the Islamic (cum classical Arabic) history of ideas, and as a living didactic tradition within select Muslim education systems that reproduce pre-modern curricula of learning. This endeavour takes into account the variegated hypotheses that emerge from within the humanistic disciplines in terms of theoretical debates over the determination of the essence of modernity and of the hitherto locked possibilities of potentially rooting thought in inherited intellectual traditions. Such a conceptual approach would be based on our critical analysis of methodologies in studying falsafa that go beyond antiquarian archival documentation, albeit without being exposed in this to the risks of anachronism or prolepsis, while also eschewing the ideological traps of reformist agendas and their promised renewal of thought in Islam. Our aim is to open up a clearing or leeway that grants a space for thinking, while also avoiding the pitfalls of arbitrariness in interpretation or rigidness in conformity, which result from entrenched habits of thought that leave their impress on scholarship without there being an affective self-consciousness of their impact. It is in this sense that a phenomenological hermeneutic approach in seeking 'things themselves' can perhaps guide the directives by virtue of which texts are read through radical questioning as a mode of eidetic reflection that mingles the remembered past with quotidian present dealings as they open up in anticipation to the future. Hence, the metaphysics of time is also implied in its ontological and epistemic underpinnings when study- 
ing intellectual history, especially in comparative approaches to philosophy, which confront us with obstacles, in addition to offering prospects that may open up the landscape of thinking to multifactorial influences. To undertake this line of inquiry, we do not engage with the prevalent reactionary currents of critiquing Orientalism (or its counterpart as Occidentalism), rather our intention is to be proactive in the production of knowledge in view of founding new directions in philosophizing that may in part benefit from renewing the impetus of falsafa. This pathway transcends mere comparativism by way of a radicalized form of questioning, which refracts and co-entangles variegated intellectual traditions with one another while being based in this on substantiated historical channels of their interconnected transmissions, and in view of inheriting past philosophical legacies within contemporary thought.

\section{Tradition}

Traditionalisms emerge in habituated receptions of what is inherited, as discursive and embodied heritage, ${ }^{3}$ as well as being reactive in relation to modernity, while being also situated in this within the unfurling of the essence of modern technology. The reflection on such phenomena preoccupied Martin Heidegger's later thought on the essence of modern technology in the manner it revealed truth by way of en-framing (Gestell), which turns being into a standing-reserve (Bestand) of locked energies and powers that respond to command in the way nature is questioned by techno-science. ${ }^{4}$ Tradition is

2

This study complements and builds upon inquiries surrounding methodological issues that I addressed elsewhere, including the following series of my publications as noted in chronological order: The Phenomenological Quest Between Avicenna and Heidegger (Binghamton, NY: Global Publications, SUNY, 2000), reprinted with an updated preface in 2014 by SUNY Press (Albany, NY); "Avicenna and Essentialism", Review of Metaphysics 54 (2001), pp. 753-778, doi http://doi.org/revmetaph200154484; "Avicenna's De Anima Between Aristotle and Husserl", in: The Passions of the Soul in the Metamorphosis of Becoming, ed. by Anna-Teresa Tymieniecka, Dordrecht: Kluwer Academic Publishers, 2003, pp. 67-89, doi: https://doi. org/10.1007/978-94-017-0229-4_6; "La perception de la profondeur: Alhazen, Berkeley, et Merleau-Ponty", Oriens-Occidens : Cahiers du Centre d'Histoire des Sciences et des Philosophies Arabes et Médiévales (CNRS) 5 (2004), pp. 171-184; "A Philosophical Perspective on Alhazen's Optics", Arabic Sciences and Philosophy 15 (2005), pp. 189-218, doi: https://doi.org/10.1017/ s0957423905000172; "Being and Necessity: A Phenomenological Investigation of Avicenna's Metaphysics and Cosmology", in: Islamic Philosophy and Occidental Phenomenology on the Perennial Issue of $\mathrm{Mi}$ crocosm and Macrocosm, ed. by Anna-Teresa Tymieniecka, Dordrecht: Kluwer Academic Publishers, 2006, pp. 243-261, doi: https://doi.org/10.1007/978-1-4020-4115-0; "Le problème de l'espace : approches optique géométrique et phénoménologique", in: $O g$ getto e spazio: Fenomenologia dell'oggetto, forma e cosa dai secoli XIII-XIV ai post-cartesiani, ed. by Graziella Federici Vescovini and Orsola Rignani, Micrologus Library 24, Firenze: SISMEL, Edizioni del Galluzzo, 2008, pp. 59-70; "The Labyrinth of Philosophy in Islam", Comparative Philosophy 1.2 (2010), pp. 3-23; "Al-Sinawiyya wa-naqd Heidegger li-tarikh al-mitafiziqa", al-Mahajja 21 (2010), pp. 119-140; "Philosophising at the Margins of Shi'i Studies: Reflections on Ibn Sina's Ontology", in: The Study of Sh'i Islam: History, Theology and Law, ed. by Farhad Daftary and Gurdofarid Miskinzoda, London: I. B. Tauris, 2014, pp. 585-597; “Le renouvellement de la falsafa", Les Cahiers de l'Islam I (2014), pp. 17-38; "Modernity, Tradition, and Renewal in Arab Thought", SCTIW Review, January 27, 2015.

Resonating our vocabulary herein with Talal Asad's take on discursive and embodied tradition as set in "The Idea of an Anthropology of Islam", Occasional Papers Series of the Center for Contemporary Arab Studies (Washington, DC, 1986).

See Martin Heidegger, "Die Frage nach der Technik", in: Martin Heidegger, Vorträge und Aufsätze, ed. by Friedrich-Wilhelm von Her- 
inescapably en-framed by modernity's technological machination. However, this does not do away with the cultural and historical differences between traditions or the fact that rational inquiry continues to be rooted in arguments and positions that are immanent in given inherited legacies, and are reinvented interpretively from within them, without descending necessarily into incommensurable cultural relativisms. ${ }^{5}$ If deconstructed leitmotifs from an inherited intellectual tradition survive in their meaningfulness within our life-world, albeit in de-contextual fragments, they are simply echoed in our age in the way techno-science shapes our modes of thinking, longing, saying, and doing. We are ordered about to respond to the command of the unfolding of technology through what exacts from us obedience without this being simply of our mere doing or wilfulness. Can we consequently philosophize by critically analysing historical philosophemes with a sense of presentism, and without being censored by archivism or antiquarianism? Or should we obey the historicist archaeological directives without seeking to overcome them in an unchartered quest for unannounced epistemic possibilities?

The past acquires its meaning in our present lived experiences, since what has passed is no longer in existence but only insofar that it is as an extant trace in physical concrete entities such as architectural vestiges, inherited artworks, codices, manuscripts, etc. These are objectively present and ready-at-hand entities, and, moreover, they offer us apophantic meanings that are depicted historically. This involves meditations on the ontological structure of time, which is already a philosophical undertaking that is frequently overlooked in the methodologies of mediaevalists when studying intellectual history. After all, history-writing and historical consciousness are not spheres of praxis that get simply determined in relation to the past as monitored in its depiction by our contemporaries as historians, they are rather present activities that, furthermore, aim essentially at addressing posterity. It is precisely this aspect of temporality that results in historicism and the need to instate methods of research in historiography. The historian aims at approximating the origin as a past milieu from which a given historical extant text or physical object presences in our world in the form of being that which has been handed down over to us as discursive or embodied heritage. Historical analysis seeks to disclose what the inherited thing gathers of elements that belong essentially to its original-lived-world by way of modelling via history-writing what pertains to its presumed origin through archiving documentation, be it in curatorial settings or in scholarly commentaries. The same applies to the reproduction of an inherited legacy through pathways of traditionalism. However, the inherited text or thing does not solely belong to the origin from which it emerged, rather in its originary character, as what presences with us, it is also destined communicatively towards us in being sent our way as what is already in our world. This is how an old manuscript, a classical text, or the propositions that constitute their logoi speak to us in a meaningful way in our lived experience. In all of these situational disclosures, time is not a linear series of past, present, and future, rather temporality gathers the three-dimensions of time in lived experience. The historian of philosophy ought to sometimes rise philosophically above historiography in examining the ontological and epistemic conditioning of the depiction of history, hence writing it via an awareness of the metaphysics of time. What survives as a trace from a past origin in our life-world belongs essentially not only to the context from which it originated, but also communicates constellations of meaning that inhere in our own world, and by virtue of handling such traces, whether textual or thingly, we destine them towards posterity. It is in this sense that the oldest of old meets 
us as a future. If an inherited textual legacy is meaningful to us, we already place it within the sphere of our life-world and render it, as such, open to the way we integrate it in our lived experience in anticipation of posterity. I do not only preserve an inheritance, but I also learn while handling it how to situate myself as a mortal with regard to those who passed as ancestors, to the ones I also encounter, face to face, as my contemporaries, and, moreover, to others who are yet to come as prospective descendants.

What calls for thinking from within about what self-announces itself as heritage belongs to our own life-world in the manner that it erupts in our everydayness as a continuing or resurgent tradition. What we take to be historical has not been concretely ruptured from the way we fashion identity within the folds of what keeps being rethought and reshaped anew within embodied and situated experiences of what pertains to discourse, scripture, and textual legacy. Archiving and preserving is a response to the passing of time, and to what determines our existential reality as mortals who are held out into the nothing in their worldly destining to death. The archival impetus is also accompanied by an ordering of knowledge in the manner it is classified and canonized. I relate to what I encounter in my readings, in my handling of codices, sources, manuscripts, as what belongs to my life world, and thus as what appears with uniqueness in my consciousness and within my own being-in-the-world. Methodology presupposes fundamental ontology, albeit it is unclear how to proceed in this regard without inviting scepticism or possibly falling prey to idiosyncrasy, revengefulness in thinking, or even nihilism.

The proclaimed objectivism in the established conventions of textual analysis is at times confronted with a postmodernist espousal of relativism or even of solipsistic idiosyncrasies in subjectivism. However, a consideration of subjectivity/inter-subjectivity in classical phenomenology has the potential of surpassing such binary oppositions by pointing at the translatability of cognitive and lived experiences across cultures and historical epochs even when the starting point involves a rootedness in a given set of interlaced traditions. It is vital to stress herein that we are rooted in an assemblage of hybrid traditions with their multifarious episteme that conditions their possibilities of knowledge. ${ }^{6}$ The historicity of intercultural entanglements in the lives of individuals cannot be denied even when concealed behind the veils of the over-dominance of a given tradition over another. We are all marked by modernity, and not simply culturally, but more essentially in terms of the systems and networks that we gather through our use of technology and in continually confronting associated emergent novel concepts and spheres of applicability. This is the case even if we claim to be traditionalists or aim at leading lives in quasi-isolation from what has become a planetary phenomenon of technological framing, or the emergence of novel appropriative concepts and

mann, Gesamtausgabe, Vol. VII, Frankfurt/ M.: Vittorio Klostermann, 2000, Chapter 1, pp. 5-36, esp. pp. 17-21. English translation: "The Question Concerning Technology", in: Martin Heidegger, Basic Writings, 2nd edition, ed. by David Farrell Krell, New York: Harper Collins, 1993, pp. 311-341, esp. pp. $322-328$.

5

Refer in this context to Alasdair MacIntyre, Whose Justice? Which Rationality?, Notre Dame, IN: University of Notre Dame Press,
1988, esp. pp. 11-13, 360-363; consult also MacIntyre's take on biology from the standpoint of Thomistic 'virtues of dependency' in his Dependent Rational Animals, Chicago: Carus Publishing, 1999, esp. pp. 1-6, 126-128.

6

To nominally evoke herein Michel Foucault's grasp of épistémé as set in his Les mots et les choses: Une archéologie des sciences humaines, Paris: Gallimard, 1968, esp. p. 13. 
transformative globalized domains of machination and praxis that become gradually mediated, domesticated, and localized.

\section{Renewal}

The question of renewing falsafa as inherited tradition cannot be readily undertaken along the pathways that have been followed hitherto by revivalists, reformists, activists, or intellectuals who viewed heritage as a source of inspiration for thought in the modern era. Some aimed at appropriating Ibn 'Arabi in modern-age spiritualism, or in Sufi cultural receptions, others posited Mulla Sadra as a pivotal figure in the traditionalist seminarian Twelver Shi'i milieu, or assimilating Avicenna (Ibn Sina) within comparative studies, or retrieving Ibn Taymiyya within Wahhabi and Salafi narratives, or picturing Averroes (Ibn Rushd) as a figure of proto-Enlightenment. The various expressions of heritage continue to exercise their impact on Muslim communities (broadly conceived) tacitly or in direct forms, especially through jurisprudence and facile as well as fragmentary, atavistic, and reactionary appropriations of religious discourse as derived from hadith, sunna, and sira. Mysticism is barely widespread, and both kalam and falsafa seem to be absent from actual practices, and figure as partial curricular components in the Twelver Shi'i hawza and at the margins of usul al-din (the foundations of jurisprudence) in Sunni settings that are open to the legacy of Ash'arism in dialectical Muslim theology. The various initiatives that aim at dealing with falsafa in a manner that can inspire modern forms of thought in Islam display trajectories that may have been marked by ideological leanings or aetiological mythmaking and eschatology in mapping out the legacies of the past anachronistically onto our own epoch. The political aspect of textual studies has a serious character to it, since the exegesis of sacred scriptures in Islam can descend into a call for violence rather than a call of conscience if not undertaken with mindfulness and an ethical rootedness in longstanding traditions with integrity and genuineness to overcome aggression and revenge through compassion and mercy. It is unclear whether we always need to consciously posit heritage as an intellectual platform for launching a reform in modern thought, or whether the depositories of past knowledge would only offer textual material for documentation, archiving, curating, collecting, or culturally entertaining the learned with intellectual curiosities. Being thoughtful in handling textual legacies allows us to approach them in a manner that could inform our contemporary intellectual concerns, while also being inclined to document them in their historical contexts with fidelity, and recognizing that in most cases we are dealing with approximations rather than actual origins and sources. Prudence is called for in view of avoiding the ideological penchant to sacralise tradition, or in radical opposition to dialectically devalue it as mere heritage. The phenomenon of going beyond the transmission of traditional knowledge or its reproduction in seeking epistemic and philosophical renewals can itself become the question to be thought, which in its own right necessitates meditations on methodology and its theoretical underpinnings or ideological motives and undercurrents. If renewal in inherited thinking is the aim, then this should accompany the endeavour to document and archive the textual traditions, which can inform comparative studies and possibly benefit from them as well. We might seek to recover the speech acts from the illocutionary propositions of previous thinkers and endeavour to disclose their intentions while eschewing the pitfalls of prolepsis in finding the meaning of the text in its future unfolding, or the drawbacks of parochialism. Such historicism 
criticizes the anachronistic approach that underpinned modernized readings. ${ }^{7}$ In contrast, pre-modern thought can be applied to contemporary theory by calling for understanding Martin Heidegger's critique of the history of metaphysics as a prerequisite for modern theorizing. Such an anti-historicist directive also draws a distinction between exoteric and esoteric meanings in texts, which may have been a stratagem of heterodox thinkers to protect themselves from political retribution or religious persecution. A hermeneutic exercise is, therefore, needed to disclose the hidden message behind a given text and the way it tackles its questions diagonally through rhetoric, wherein philosophizing becomes an ahistorical theorizing that becomes inspired by tradition while transcending its relativizing determinants. ${ }^{8}$ In all cases, drawing inspiration from past intellectual traditions requires prudence and thoughtfulness to avoid the ideological leanings that may motivate such an endeavour, and in view of not betraying the original authors or distorting their teachings. If the Islamic intellectual heritage can be of inspiration at the philosophical level, it cannot simply be construed from the perspectives of sectarianism, traditionalism, relativism, national or religious revivalism; rather, its universal value should be brought forth in renewing philosophizing per se. However, ancient ideas are not timeless, nor are they readily valid across historical epochs. Pre-modern concepts should not agree a priori with the intentions of the exegete or commentator, despite the pre-suppositional hermeneutic foresight and prejudice that determine the derivation of meaning in textual reading.

The academic conventions of mediaeval Arabic cum Islamic studies hinder the examination of falsafa through the prisms of contemporary concerns in epistemology, ontology, logic, or theory of value, they rather posit it in mainstream academia as an historical textual legacy that has already been surpassed and is disconnected from modern thought. This calls for thinking about the implications of the modern methods in historiography, philology, codicology, lexicography, and palaeography, with their biographical/bibliographical instruments, which are used in studying pre-modern texts in science and philosophy that were transmitted primarily through the Arabic language in classical Islamic cultural settings. These prevalent approaches orient by convention the investigation of the histories of ontology and epistemology from the perspectives of archival documentation, antiquarian archiving, literalism in translation, and the presupposition of a detached objectivity in the professed controlled contextualization of research. Such dominant processes are dialectically contrastable with situational hermeneutic and epistemic orientations that involve critical interpretations of the conceptual entailments of pre-modern science and philosophy on contemporary theories of knowledge. The prevailing modes of inquiry in mediaevalist studies ought not to remain insulated and isolated from hermeneutic theory, phenomenology, philoso-

This is for instance the approach in: Quentin Skinner, Visions of Politics, Volume 1: Regarding Method, Cambridge: Cambridge University Press, 2002, esp. pp. 7, 74, 115, 119, 121, doi: https://doi.org/10.1017/ cbo9780511790812; Quentin Skinner, Meaning and Context: Quentin Skinner and his Critics, ed. by James Tully, Princeton: Princeton University Press, 1988, esp. pp. 29-32, 38-41, 57-64, 109-111; Quentin Skinner, "Meaning and Understanding in the History of Ideas", History and Theory, Vol. 8 (1969),
No. 1, pp. 3-53, esp. pp. 12-13, 16, doi: https:// doi.org/10.2307/2504188.

8

See in this regard: Leo Strauss, Persecution and the Art of Writing, Glencoe, IL: The Free Press of Glencoe, 1952, pp. 24-25, 30-31; Leo Strauss, What is Political Philosophy and Other Studies, Glencoe, IL: The Free Press of Glencoe, 1952, pp. 10-14, 17-18; Leo Strauss, The City and Man, Chicago: University of Chicago Press, 1964, pp. 1-8. 
phies of history, science, and religion, and the meditations on the metaphysics of time, ontology and epistemology.

Studying the impetus of philosophizing in relation to Islam from a contemporary standpoint in philosophical thinking remains a desideratum that points to diverse obstacles. Some of these may be un-exhaustively summarized as follows: 1) Historical (since falsafa is principally posited as being mediaeval); 2) Cultural (by assuming that falsafa is oriental, even if transmitted in assimilated fragments within European thought); 3) Textual-archival (that is bent on studying inherited extant objects as codices, manuscripts, epistles); 4) Islamized (by resisting, prudently or dogmatically, the "contamination" of traditionalist Islamic legacies with "alien" philosophical sources, while disregarding the fact that falsafa remained in its hybridity Hellenized). Such misconceptions are coupled with a historicist angst regarding anachronism and authenticity, which can be gradually surpassed or placated by opening up the horizons of reflection on universal questions in epistemology, ontology, logic, and theories of value.

Falsafa is animated with tafalsuf, since philosophy happens by philosophizing and not simply through analytic documentation. If the aim is to contemplate the question of renewing the impetus of philosophizing in relation to the history of ideas in Islam, and in view of developing a neo-falsafa that is contemporary, and that retains epistemic, hermeneutic, cognitive and textual interconnections with Islamic intellectual histories, then this ought to avoid randomness or ideology. Appealing to history ought to be a cautioned mode of thinking that does not succumb uncritically to tradition with reactionary atavism. Intellectual exercises that have specific epistemological, ontological, or logical trajectories can offer contexts for rethinking how to revive some leitmotifs of historical provenance that can prospectively inform our current reflections on the question of being in a techno-scientific age that entraps our thought, or yields traditionalisms that face our planetary epoch of technicity with a fragmentary quasi-resistance or revengefulness.

The potentials of emancipation and the generation of novel schools of philosophy in this present century, by way of being inspired by intercultural and interlaced intellectual histories, cannot be arrested nor compromised by succumbing to the restrictions imposed by the custodians of archives within the ranks of mentoring classicists and mediaevalists. The dominance of inherited models in studying falsafa as entrenched in the oldest prestigious institutions of higher learning is no longer sustainable without a broadened philosophical horizon that guides such inquiries. Moreover, the construction of knowledge, its dissemination, adaptive reception, and interpretative assimilation cannot all be contained by the rules of reportage and documentary archiving. The intellectual heritage of a people cannot simply be posited as relics from the past that can only be studied through the narrow channels of academic expertise in documenting and curating. This is especially the case if such heritage is still a living source of cultural inspiration for multiple communities, and partly shapes in tacit forms some of their inherited and renewed outlooks on the universe concerning truth, goodness, beauty, justice and governance. This is clearly the case with respect to the history of philosophical and scientific ideas in Islam, which reflects on socio-cultural dimensions that classicists, mediaevalists, and scholars of Oriental studies do not fully acknowledge or recognize, or possibly refuse to do so. This state of affairs reveals the need to be more directly engaged in critically analysing these past legacies from the viewpoint of the potential connection of their fundamental elements with 
contemporary concerns in thinking and practice. Greater possibilities are now available for studying the classics through developments in narrative analysis, critical theory, post-modernist discourse, the technicalities of epistemology and logic in the Analytic School in philosophy, along with the unfolding of the horizons of fundamental ontology, hermeneutics, phenomenology, and deconstruction in Continental Thought, or Critical Theory, etc. All offer enriching differential potentials for the renewal of philosophical inquiry and intellectual exchange across cultures, and yet this ought to be undertaken dialectically in the sense that modern theorizing and analytics would be critically challenged based on inherited views from the tradition. The modern and the traditional would be, therefore, co-entangled in thinking, even if marked by tension in their connections and distinctions. After all, to be modern is to bring newness, which in itself necessitates that there is that which has been inherited that may need to be transcended, hence positing in a dialectical manner what is surpassed by way of leverage in the form of renewal.

Although modern theorizing can unlock the philosophical potentials within inherited intellectual traditions, it remains essential to rely in such inquiries on established critical editions of manuscripts, the production of annotated translations, and the setting of exegetical commentaries that render the classical sources accessible, even by way of approximating reconstructions that do not amount to ur-texts. Such aims in scholarship are noble and may be sufficient from the viewpoint of establishing the classical codices on sound historical and textual grounds. However, from perspectives that surpass the purposes behind instating such conventions, the central concerns are epistemic, cognitive, and cultural in terms of seeing in what way the history of thought informs contemporary debates in philosophy and the modulation of their associations with science, religion, art, politics, and ethics. Do historical precedents have implications with respect to inspiring, informing, or dialectically differing from our contemporary outlooks on the human condition, the cosmos, divinity, truth, goodness, beauty, and justice? Can they elucidate our grasp of the evolution of concepts and the taxonomies of knowledge and its canonization? What value do they bring to discussions regarding epistemology, ontology, logic, and value theory?

\section{Comparative pathways?}

Establishing comparative studies in relation to classical texts and authors ought to take certain precautionary methodological steps that can be validated from the viewpoint of history-writing, and by un-concealing the distinction between traditions in terms of their historical and cultural differences. To avoid a direct confrontation with the methodological strictures that are associated with the investigation of classical texts, it is more prudent if comparative inquiries are initially undertaken with respect to legacies that have well-documented historical and textual interconnections. In the case of the history of ideas in Islam, the focus would be directed towards the linguistic and conceptual transmission of knowledge from Greek into Arabic (and in many cases via the agency of Syriac), or from Arabic into Latin (and occasionally via the agency of Judeo-Arabic and Hebrew). Such procedures set a context for the comparative historical study of texts and their intercultural adaptations within interlinked intellectual traditions. Accordingly, it would not be controversial if comparative inquiries focus on the reception and response to the philosophical legacy of Ibn Sina (Avicenna) or Ibn Rushd (Averroes) by 
Thomas Aquinas or the European scholastics, or that Muslim philosophers are compared with their Greek and Late antiquity predecessors through the lines of transmission of knowledge. The same can be said about the investigation of the assimilation of the scientific oeuvre of Ibn al-Haytham (Alhazen); his Kitab al-manazir (De aspectibus / perspectivae) by thirteenth century Franciscan opticians at Oxford, Paris and Padua (such as Roger Bacon and then Witelo), and later by Renaissance perspectivists since the trecento (such as Biagio Pelacani da Parma, Paolo dal Pozzo Toscanelli, Lorenzo Ghiberti). Such inquiries are usually considered acceptable from the standpoint of the history of ideas. However, the conceptual and methodological elements become more complex and ambivalent, or even doubted by some classicists or mediaevalists, when the analysis is undertaken from the viewpoint of contemporary debates in philosophy. This issue becomes further complicated, and faces greater opposition, when examining the multifarious traditions of historical-falsafa through pathways in thought that do not veil their own modern philosophical consciousness and leanings.

The investigation of falsafa as an historical legacy within the curricula of mainstream European-American academia presupposes an archaeological bent on studying the history of philosophy in relation to Islam. Such a penchant regulates the methods of the guardians of archival documentation. The historian of ideas studies the intellectual history of Islam in the spirit of an antiquarian compiler of knowledge who reports the textual material and endeavours to document it in order to primarily serve the establishment of library references that involve narrations about past cultures. The objectives of such exegetes and custodians of archiving differ from the purposes of philosophers who focus on the evolution of concepts and on the renewed reformulation of questions in ontology, epistemology, logic, or value theory.

The dominant methodologies have been historically shaped by the development of classicist and mediaevalist methods in studying Greek and Latin manuscripts (or critically editing the Bible), which ultimately directed the transference of scholarship to the investigation of Islamic pre-modern textual sources within the trajectories of Orientalism. This state of affairs should not, however, be addressed through dogmatic or apologetic reactions towards the so-called 'Eurocentric' methods in research. Orientalist scholarship facilitated the retrieval of non-European textual legacies and assisted in situating them in their historical-cultural milieu, albeit still requiring reform in view of rewriting many chapters in history of philosophy and science. Critique in this context need not be motivated by a depreciating resentment, nor should it amount to relativism, even if it articulates aesthetic, ethical, or political positions.

Additional difficulties in research arise from the manner pre-seventeenth century history of science and philosophy does not figure more prominently and visibly in contemporary philosophical thought. Philosophers feel less restricted in studying figures such as Descartes, Leibniz, Kant or Hegel, than they do when dealing with thinkers from earlier epochs. Moreover, many contemporary philosophers are understandably preoccupied with responding to colleagues and reforming the systems of their mentors, let alone dealing with early-twentieth century legacies (G. Frege, E. Husserl) that are themselves receding from mainstream philosophy curricula. Exceptions do emerge, such as with neo-Thomism, despite its theological associations, or the analysis of Aristotle's De anima in relation to the philosophy of mind, but these remain marginal with regard to current trends in contemporary philosophizing. Accounting for falsafa within mainstream philosophy curricula (especially in 
non-Muslim contexts) remains embedded within the folds of mediaeval European thought in mediaevalist studies. As for the reproduction of falsafa in selected contemporary Muslim religious circles, it takes into account some of the pressing lived problems of socio-politics, ethics, and the applications of the religious law, while being tacitly based in this on traditionalist ontological, epistemological, and cosmological outlooks that have not been thoroughly reformed since pre-modern times. One poignant example that presents itself in this regard is embodied in an implicit presupposition of a pre-Keplerian cosmology when reflecting on the questions of metaphysics in relation to Islam. It is unclear what type of cosmology emerges from within Muslim thought that takes into account the developments in modern astrophysics, or how the mind/body problem is reconsidered against the background of neuroscience and consciousness theories, ${ }^{9}$ or in upholding spiritualism in an era that is focused on artificial intelligence and bio-mimetic robotic technologies. Such issues pertain to thinking about the connection and distinction between science and religion. Falsafa can either begin to engage with these questions despite the tremendous difficulties that this places on thought, or remain reproductive in narrow traditionalism, or simply be posited as archival material.

The traditions of falsafa, even in their strict commitment to Aristotelian teachings, would have tended towards a doubling of reality in Platonic expressions that resonated with the onto-theologies of Abrahamic monotheism. The real is doubled in the manner the appearances are posited as copies of archetypal eidoi. Analogically, the onto-theological super-sensory reality is contrasted with the corruptible physical universe of appearance. Nonetheless, this classical picture and parlance that is derived from a Greco-Abrahamic hybrid consciousness can be meditated upon in a more fundamental manner by rethinking the ontological difference between being and beings as what underpins the question of the meaning, place and truth of being. The question to be thought in the manner of our worldly being is that of achieving equipoise between the materialist consumerism of our capitalist age and the tendencies within religion to nurture at its mystic margins the ascetic tendency that turn our back on worldliness. Real being has a transcendental character in being noetically thought by means of concepts without becoming transmuted into a psychical being, and yet being is reflected upon in connection with time.

In reflecting on the possibilities of renewing the impetus of philosophizing in relation to Islam, and thus in rekindling the potential rehabilitation, renovation, and reanimation of falsafa in contemporary terms (with what this carries as entailments with regard to kalam and fiqh [jurisprudence/law]), a measured prudence ought to be exercised to avoid distortions. One's own voice as interpreter ought to be clearly distinguished from that of the original author of a historical text in order to show with lucidity where deviations and new propositions are presented, and in how these belong to the spheres of critical analytics and hermeneutics, instead of being part of the textually-oriented practice of documentation. This state of affairs doubles the interpretative activity to ensure that the classical text is soundly situated in its originary context and in terms of its documented interconnections with other constellations of texts and pathways of transmission across languages and intellectual traditions. This activity can be intertwined with analyses that lift some of the old propositions from their narrowly determined historical spheres, by way of

9

See Nader El-Bizri, "Avicenna and the Problem of Consciousness", in: Consciousness and the Great Philosophers, ed. by Stephen
Leach and James Tartaglia, London: Routledge, 2016, pp. 45-53. 
assessing their potencies in generating renewed and innovative horizons for philosophical thinking. Such matters fall within the professional academic domain of the career-oriented study of philosophy, but not so much in terms of history, and especially so in relation to Islam. However, some philosophers find themselves personally torn between contemporary philosophy on the one hand (with its various branches, quarrels, and most prominent Analytic-Continental bifurcations or recent rapprochements), and interest in other intellectual traditions that do not belong in their entirety to modern AmericanEuropean philosophy, on the other. Hence, they find themselves situated in a region between philosophies that are narrowly labelled as 'Western' or 'Occidental' (with the looseness of such misguiding appellations) and the intellectual heritage of non-European cultures (Chinese, Indian, Persian, Turkish, Arabic, etc.). The biographical and intimately personal becomes intricately interwoven with the conceptual and academic, in such a way that areas of specialization and concentration result in sets of publications and communications that address topics that seem to be incommensurable or incompatible. Philosophers who find themselves in such circumstances seem to deal with aporetic antinomies while mediating multiple intellectual loyalties and validating their hybrid forms. The individual scholar would have to modify themes, methodologies, and procedures of disseminating research in view of serving narrowly delimited spheres of study, which separate contemporary philosophy from the historical depositories of wisdom and knowledge in nonEuropean traditions. It, therefore, becomes an urgent call for thinking this question by those who find themselves trapped in this liminal region of the in-between that we are driven more pressingly to occupy within this current century. We, therefore, start with conversations, exchanges at the margins, and through comparative studies. Eventually, the intensification of such activities may result in works of synthesis, isomorphic unification, and the merging of horizons, which offer novel possibilities for thought and the renewal of philosophical thinking beyond mere comparativism. In this process, many thinkers will continue to adjust their intellective persona depending on their academic readership and scholarly audience, along the lines of dividing disciplines and oscillations over fissures in their philosophical thought, while proceeding by way of leaps from one intellectual tradition to another.

It is unclear whether the investigation of falsafa in the shadows of Islamic studies has the potential of connecting with contemporary philosophy beyond comparative analytics. Would falsafa emerge in novel forms in our current century that render it a relevant school of contemporary thought in response to modernity, techno-science, the organization of the models of modern episteme and material culture? The interrogations that we have advanced so far point to aspirations that are marginalized within the academic procedures that separate Islamic studies from philosophy in the university curriculum under the methodological control of authoritative peers. These concrete aspects of academic life, the cultivation of scholarship, the destining of individual apprentices on career-paths, and the educational shaping of the formative constitution and aggregation of academics, all point to the actual practicalities of specializing in the so-called 'Islamic philosophy' that usually results in being externalized from philosophy. Besides such obstacles, the divisions within contemporary philosophy enact additional epistemic barriers. The engagement with the history of philosophy from a contemporary standpoint is principally conducted within the Continental School in terms of the manner in which it mediates some of its central investigations via critical reinterpretations of the history of philosophical and scientific ideas. Numerous controversies arise 
within this contemporary movement in philosophizing. For instance, a focus on Heidegger's critique of the history of metaphysics, which is undertaken against the horizon of the unfolding of science and the essence of technology, is itself burdened by quarrels within the field of Heideggerian studies and its reception by philosophers from other intellectual traditions (disputes arise over the interpretation of technical Heideggerian terms, or with regard to the determination of the course of development of Heidegger's thought, or the translation of Heidegger's oeuvres). Additional polemics emerge in terms of the political shadows that are recast in recurrent patterns over Heidegger's biography, or by way of the diverse forms of opposition that his thought continues to face from Husserlian phenomenologists and Analytic philosophers, along with controversies that arise in terms of reading his oeuvre through the writings of J.-P. Sartre, J. Beaufret, J. Derrida, and E. Levinas. These multiple hurdles become higher and frequently established when we consider the interpretation of the history of philosophy through Heideggerian perspectives. Classicists, mediaevalists, phenomenologists, and analytic philosophers would raise differential doubts regarding such undertakings. Such polemics become hypercritical when an attempt is made in terms of interpreting the ontology of Ibn Sina (Avicenna) from the standpoint of Heidegger's critique of the history of metaphysics, despite the fact that Avicennism (al-sinawiyya) does not only belong to Islamic intellectual history, but is also part of the history of European thought, at least in its Latinate scholasticism, and that it was seen by Heidegger as being pivotal in the unfolding of metaphysical thinking. ${ }^{10}$ Reading Avicenna's analysis of the modalities of being in terms of necessity, contingency and impossibility need not rest on an emanation theory or on an idiom that is solely informed by the parlance over causal connections and movement from potentiality into actuality, hence opening up a novel sphere of ontological thinking that has a starting point in the focal elements of Avicennian ontology without being constrained by conceptual structures that belong to scholastic thought and mediaeval outlooks on reality. This can be undertaken in terms of critically rethinking Heidegger's critique of metaphysics by studying the ontology of Avicennism, and surpassing both towards a new direction in ontological thinking that does not fetishize its sources.

The conceptual circumstances are perhaps less harsh when focusing on the oeuvre of Maurice Merleau-Ponty. Nonetheless, reading the history of science from a phenomenological viewpoint is not without its epistemic and methodological obstacles. These take more severe expressions when the inquiry focuses on the scientific legacies of polymaths like Ibn al-Haytham (Alhazen), in spite of his direct influence on the history of optics in Europe, and even on architectural and artistic practices within the perspectiva traditions of the Renaissance. The pathway in this line of inquiry would be that of historical epistemology as a form of practicing history and philosophy of science as an architectonic unity and not mere multi-disciplinarity.

\section{Impasses/horizons?}

We return again to the question to be thought, namely: How can we account for falsafa in contemplating the locked and suspended philosophical possibilities that remain concealed within the labyrinthine folds of arrested intel-

10

This is precisely what I have done in many of my studies on Avicenna. 
lectual histories? We reflect in this sense on the horizons of the renewal of the impetus of philosophical thinking in relation to the history of ideas in Islam, which surpass the limitations of academic assignments, in view of genuinely desiring the unfolding of original thought that is re-collective, de-structuring, and re-constructive in its modes of revealing the gravity of critically rethinking our inherited conventional methodologies and their concealed theoretical presuppositions.

When reading a classical text, be it in a printed critical edition of a primary source or in a manuscript, a methodological set of procedures is applied in attempting to grasp the meaning of what is being read. The act of reading is itself interpretative even at the analytic level, and many internationallyacclaimed mediaevalists mediate their reading of an Arabic (Persian, etc.) pre-modern opus via its translation into a European language as a pathway to grasping its meaning. Deciphering the language and its grammar is coupled or followed by an attempt to derive the sense of the propositions, and hence of also subjecting them to an assessment of their truth values and linking them to whatever prior knowledge we have about the author, the text, the constellation of works it belongs to, and the contextual aspects of its intellectual setting and cultural milieu, including lines of transmission and adaptation of precedent and posterior channels of influence and connectivity. We bring a whole body of prior knowledge to bear on reading, or on an attempt to edit, or even to translate, annotate, and compose a commentary. We endeavour to bracket our own biases, or prejudices, and the cognitive as well as hermeneutic leanings that belong to our critical, analytic, conceptual, and epistemic presuppositions. And yet, meaning does not arise without an integration of what is being read within our configurations of knowledge, comprehension, and lived experience in flux. The text is given to our consciousness in intuitive experiencing as being objectively present at hand, and in this as being already embedded in our lived experience and marked by its affects, no matter how much we endeavour to receive it in its own reconstructed milieu with detachment. The text is a thing that is given to my consciousness and my experiencing in the here and now, with what this entails as mood, readiness in cognition, recollection, imagining, and preoccupation with near and distant other minds, things, or state of affairs that aid my reading or pull my care and attentiveness towards quotidian everyday dealings. These bring about the manner in which we picture our peers, our predecessors, and the future readers of our commentaries and interpretations. We are mortals who gather the fragments of worlds that passed, which leave their traces as inherent things in our own worldliness and destine them to posterity through the way we handle them in our being-in-the-world.

Interpreting what has been handed down to us as a textual legacy can be handled prudently by turning our analysis into mere paraphrasing. Such literalism and antiquarianism avoids the hermeneutic recognition of the manner by which the inherited text also belongs to our own world, and is hence marked by presentism and by prejudices that need to be identified and assimilated dialectically in the way the textual content is revealed as being meaningful to us, and in how it speaks to our consciousness, to our epistemic preoccupations, cognitive frames of mind, and embodiment as subjects with others in the world. Such hermeneutics would translate the text in an interpretative manner that renders its propositions comprehensible within our own lived use of language. These aspects become more pronounced when dealing with philosophy, since many of its problems are reformulated and necessitate phi- 
losophizing rather than solely meeting the exacting requirements of grammarians, philologists, archivists, or historians. This becomes clearer when dealing with mathematics and thinking about its notions as being universal within the systems that render their content communicable, be it formalised in notation symbols, in equations or geometric figures, or described in idiomatic ways. The propositions of philosophy and the statements of the exact sciences are epistemologically relevant to our own spheres of modern knowledge and cannot be read independently from our own epistemic and cognitive commitments even if we endeavour to maintain our fidelity to the origins from which they have been destined our way. One has to judge the logical aspects of a given declaratory statement in order to determine its truth or falsity as a proposition that points to a specific phenomenon or state of affairs. This logic of judgment assesses how a semantically determinate statement logically attributes a predicate to a corresponding subject, versus indeterminacy in sentences that make such attribution in a contingent manner rather than by way of necessity. The truth of a determinate proposition is supported by evidence and is verifiable more than an indeterminate one.

Antiquarian and literalist approaches in the analytics of contextualized textual studies ought to be coupled with a hermeneutic awareness of present knowledge and lived experience, otherwise, the claim of objectivity can be misleading and lacking in consciousness about what takes place when reading a text, if not veiling such situational experience via unreformed methodologies and orthodoxy in conventions. History is an objective reality through what it leaves for us as traces that constitute the communicative locus of inter-subjectivity, or the meeting place of the consciousness of mortals across time, and in revealing our belonging to a shared humanity through empathy, reciprocity, and hospitality. The objectivity of history is also in essence a subjectivity of historicity and not simply entangled with the subjective nature of the historian. ${ }^{11}$ The experiencing of history is threatened to no longer have a home in being simply an archival matter, and yet history takes its revenge upon those who are estranged from it through their uprooted fragmentation of culture. Moreover, thinking has to address the epochal moment of the world and not block the way to reflection upon the essence of planetary modern technology, and thoughtfully experience what its nature is based upon. The fact that an inherited textual legacy is meaningful to us already places it within the sphere of our life-world and renders it as such open to the way we integrate it in our quotidian dealings as embodied mortals, and in our anticipations of what opens up as a future. I do not only preserve what is inherited but also learn while handling it how to situate myself as a mortal with regard to those who passed, and to the ones I encounter face to face, and to those others who are yet to come as posterity. It is from my mortality that I am in time, inherit by habituation or learning a tradition, deconstruct it in my embodied life, and hand it over in fragments or by way of renewal as a preserved inheritance for the future. 


\title{
Nader El-Bizri
}

\section{Falsafa: labirint teorije i metode}

\begin{abstract}
Sažetak
Ovaj rad istražuje teorijske osnove metodologija koje se koriste u proučavanju falsafe (poznate $i$ kao 'arapska i islamska filozofija'). Nakana je promisliti perspektive obnavljanja izabranih lajtmotiva iz konstelacije hibridnih filozofskih tradicija $u$ falsafi $u$ sklopu transcendiranja konvencija glavnih škola i učenja, uz njihovo naginjanje dokumentiranju, arhiviranju te sastavu komparativnih studija i komentara. Tematska orijentacija ovog istraživanja ne slijedi upute medijevalista u historiografiji, filologiji, leksikografiji, kodikologiji i paleografiji, skupa s biografskim/bibliografskim alatima koji su s njima povezani. Prema tome, ne usredotočujemo se na specifične predmoderne autore ili tekstove, niti se zadubljujemo u tehnike uspostavljanja kritičkih izdanja, prijevode popraćene bilješkama, niti analitičke, historijske i komparativne komentare. Također, ne nastojimo situirati dano filozofsko nasljeđe unutar njegovih kanala tekstualne transmisije, niti istražiti njegov tijek razvoja s obzirom na određeno intelektualno podrijetlo. Naše je istraživanje zapravo usmjereno na ovu specifičnu konceptualnu vježbu kroz fenomenološku hermeneutiku i kritičku analizu teorijskih osnova onih metodologija koje teže istraživanju bitnih pitanja u ontologiji i epistemologiji, koja su povezana s falsafom. Time se ukazuje na transcendiranje pukog komparativizma putem radikalnog oblika propitivanja koje lomi intelektualne tradicije s propitivanjem što je utemeljeno na suštinskim historijskim kanalima transmisije u nasljeđivanju filozofskih baština unutar suvremenih pravaca u mišljenju. Takav je pothvat usmjeren na različite hipoteze koje izranjaju iz humanističkih disciplina u smislu teorijskih rasprava i ispitivanja o bîti suvremenosti i sondiranju dosad zapriječenih mogućnosti potencijalnog ukorjenjivanja suvremenog mišljenja u naslijeđenim intelektualnim tradicijama, kao i u polučivanju praktične koristi iz modernog mišljenja u istraživanju historije ideja $u$ islamu kao živoj tradiciji.
\end{abstract}

\section{Ključne riječi}

komparativizam, falsafa, metodologija, suvremenost, religija, znanost, teorija, tradicija

\section{Nader El-Bizri}

\section{Falsafa: ein Labyrinth der Theorie und Methode}

\section{Zusammenfassung}

Diese Abhandlung untersucht die theoretischen Grundlagen von Methodologien, die bei der Erforschung der Falsafa (oder was gemeinhin als ,, arabische und islamische Philosophie“ bekannt ist) verwendet werden. Die Intention ist es, über die Perspektiven der Erneuerung ausgewählter Leitmotive aus der Konstellation hybrider philosophischer Traditionen in Falsafa nachzudenken, während man die Konventionen der vorherrschenden akademischen Welt und der Gelehrsamkeit, mit deren Hang zur Dokumentierung, Archivierung sowie zur Komposition von komparativen Forschungen und Kommentaren, transzendiert. Die thematische Orientierung dieser Forschung folgt nicht den Richtlinien der Mediävisten in der Geschichtsschreibung, Philologie, Lexikografie, Kodikologie sowie der Paläografie, zusammen mit ihren dazugehörigen biografischen/bibliografischen Instrumenten. Wir fokussieren uns daher weder auf spezifische vormoderne Autoren oder Texte, noch vertiefen wir uns in die Techniken der Schaffung kritischer Ausgaben, der Übersetzungen mit Anmerkungen oder analytischer, historischer und komparativer Kommentare. Wir versuchen auch nicht, das gegebene philosophische Erbe innerhalb seiner Kanäle der Texttransmission zu situieren oder dessen Entwicklungsverlauf innerhalb einer bestimmten intellektuellen Abstammung zu erforschen. Ausgerichtet ist unsere Untersuchung vielmehr auf die spezifische konzeptuelle Übung durch phänomenologische Hermeneutik und kritische Analytik der theoretischen Grundlagen jener Methodologien, die darauf abzielen, wesentliche Fragen in der Ontologie und Epistemologie im Zusammenhang mit Falsafa zu inspizieren. Dies deutet auf die Transzendierung des bloßen Komparativismus durch eine radikale Form der Forschung hin, die mit intellektuellen Traditionen bricht, zusammen mit einer anderen Forschung, die auf der Grundlage fundierter historischer Transmissionskanäle in der Vererbung vergangener philosophischer Hinterlassenschaften innerhalb der zeitgenössischen Denkbahnen fußt. Ein solches Unternehmen adressiert multifaktorielle Hypothesen, die aus den humanistischen Disziplinen hervorgehen, unter dem Aspekt der theoretischen Dispu- 
tationen und Befragungen über das Wesen der Modernität und der Sondierung der bislang versperrten Möglichkeiten der potenziellen Verwurzelung des zeitgenössischen Gedankens in geerbten intellektuellen Vermächtnissen, wie auch im Profitieren von dem modernen Denken bei der Erforschung der Ideengeschichte des Islam als lebendige Tradition.

\title{
Schlüsselwörter
}

Komparativismus, Falsafa, Methodologie, Modernität, Religion, Wissenschaft, Theorie, Tradition

\section{Nader El-Bizri}

\section{Falsafa : un labyrinthe de théorie et de méthode}

\begin{abstract}
Résumé
Ce travail recherche les principes méthodologiques théoriques utilisés dans l'étude de la falsafa (ce qui est communément connu sous le nom de "philosophie arabe et islamique »). Le but est de penser les possibilités de renouvellement de certains leitmotivs, sélectionnés sur la base d'une constellation de traditions philosophiques hybrides présentes dans la falsafa, tout en transcendant les conventions des principaux courants académiques et de leur enseignement, mais également en se penchant sur leur intérêt pour la documentation, l'archivage et l'élaboration d'études comparées et de commentaires. L'orientation thématique de cette recherche ne se tient pas aux instructions médiévales concernant l'historiographie, la philologie, la lexicographie, la codicologie, et la paléographie, ensemble avec leurs outils biographiques/bibliographiques. A partir de là, nous ne nous concentrons pas sur les auteurs et les textes pré-modernes et n'entrons pas en profondeur dans les techniques de mise en place d'éditions critiques, de traductions annotées, ou encore, de commentaires analytiques, historiques et comparés. De même, nous ne cherchons ni à situer l'héritage philosophique donné à l'intérieur des canaux de transmission textuelle, ni à explorer le cours de son développement en regard d'une lignée philosophique particulière. Notre recherche est davantage orientée vers cet exercice conceptuel spécifique, à travers la phénoménologie herméneutique et l'analyse critique des principes méthodologiques, qui s'applique à rechercher les questions essentielles en ontologie et en épistémologie, à savoir les questions liées à la falsafa. Ainsi, nous mettons l'accent sur le dépassement du simple comparatisme à travers une forme de questionnement radical qui rompt avec la tradition philosophique par le biais d'un autre questionnement, fondé sur des canaux historiques essentiels de transmission qui ont hérité du patrimoine philosophique à l'intérieur des lignes contemporaines de pensée. Une entreprise de la sorte se concentre sur les diverses hypothèses qui émergent des disciplines humaines en termes de débats théoriques et d'interrogations portant sur l'essence de la modernité, et examine les possibilités, jusqu'alors fermées, d'un enracinement potentiel de la pensée contemporaine dans l'héritage du patrimoine intellectuel, tout en recherchant les gains d'ordre pratique résultant de la pensée moderne dans le cadre de sa recherche sur l'histoire des idées dans l'islam en tant que tradition vivante.
\end{abstract}

\section{Mots-clés}

comparatisme, falsafa, méthodologie, modernité, religion, science, tradition 